\title{
都市における生物多様性保全に向けた緑の基本計画策定手法の現状と課題 \\ Current trends and issues in methods of making Green Master Plans for urban-biodiversity conservation
}

\author{
曽根 直幸* 上野 裕介* 栗原 正夫* \\ Naoyuki SONE Yusuke UENO Masao KURIHARA
}

\begin{abstract}
The conservation of urban biodiversity has been promoted under international processes such as the Convention on Biological Diversity. Thus, municipal governments in Japan are each required to plan ecological networks in a "Green Master Plan" (GMP). In this study, we have discussed current trends and issues in methods of creating GMPs for the conservation of urban biodiversity, by examining 20 plans which had been selected as the best examples of excellence. Specifically, we aimed to answer the following questions: (1) How do the present GMPs deal with urban biodiversity? (2) What problems are there for conserving urban biodiversity by means of a GMP? (3)What kind of scientific knowledge can we apply in order to solve those problems? Our examination revealed that there are few GMPs in which an ecological network is planned concretely and effectively, and that there are several problems for each planning procedure. In addition, a variety of previous works on urban ecology in Japan was collected and looked at from the viewpoint of finding solutions for these problems. Future research tasks were then argued.
\end{abstract}

Keywords: Biodiversity, Green Master Plan, urban ecology, ecological network キーワード：生物多様性, 緑の基本計画, 都市生態学, エコロジカルネットワーク

\section{1. 研究背景と目的}

地球環境問題の主流化を背景に，都市においても生物多様性保 全への要請が高まっている。生物多様性保全を都市計画に反映す る際には，生物の生息環境の保全や，生態系サービスの利用，エ コロジカルフットプリント等の観点が重要となる ${ }^{12)}$ 。特に都市で は生物の生息環境亡なる水と緑の豊かな自然的環境が限られてい る 1)ことから, 緑の基本計画を活用し, 緑地等の保全・再生・創 出を図ることが重要である2)。しかし緑の基本計画については,

「具体的にどのような生物多様性を保全するか，保全すべき生態 系のイメージは何か, 構想はしたものの実際に都市計画・地区計 画レベルの計画に落としきれているか，生物多様性の保全が実現 されているかを検証できているか，など」の技術的な課題も指摘 されている ${ }^{3)}$ 。生物多様性保全策として実効性ある計画立案と実 施のためには，緑の基本計画の現状と課題の把握，根拠となる生 態学等の知見の整理と活用が求められている。

生物多様性保全策としての緑の基本計画に関寸る先行研究とし ては，流域圈やエコロジカルネットワーク（以下，EN）の観点 からそのあり方を論じたもの4), 5)，先進事例を紹介したもの6) がある。また，基本的な考え方と手順を示したもの》や，特定の 種の生態や複数分類群の移動能力などの観点に着目し計画策定に 応用可能な知見を整理したもの 8). 9). 10)がある。一方，複数の計画 を生物多様性保全策としての機能の観点から横断的に整理し，全 般的な現状と課題について分析した研究や，計画の検討項目に沿 って生態学などの活用可能な知見を整理した研究など，多くの地 域における具体的な計画立案に資する研究は見られない。

そこで本研究では，まず1）生物多様性保全策として特に生物 の生息環境の保全の観点から緑の基本計画の現状と課題を明らか にし, 次に 2) 既往研究を計画の検討項目に対応した形で整理し なおし，科学的知見を活用した計画策定の方向性や今後の研究課 題を明らかにする。

\section{2. 研究方法}

\section{（1）緑の基本計画の収集と分析 : 優良事例への着目}

本研究では, 650 市町村 (2012 年度末時点) で策定されている 緑の基本計画から選定された最優良事例 22 計画 11 のうち HP で 公開されている 20 計画を対象とした。これらは, 最近 10 年間に 新たに策定・改訂された計画のうち内容や策定プロセス等の優れ ている計画が選定されたものである。生物多様性保全の実効性を 高めるには，法定計画である緑の基本計画への位置づけが有効だ が，前提として行政内外に影響力を発揮できる優れた計画である 必要がある。そこで本研究では, 内容や策定プロセス等全般が評 価された優良事例を対象に生物多様性保全がどう計画されている か整理することが，生物多様性保全策としての緑の基本計画の現 状と課題を把握する上で適切な方法と考えた。

分析では，まずそれぞれの計画の策定目的に都市における生物 多様性保全の観点が含まれているかを確認し, 次に国土交通省都 市局（2011）2)に示された検討項目に沿って視点を整理し，対応 状況に関する評価区分（A，B，C）を設定した（表－1）。評価区 分は，配慮事項 2)に対応した検討を行い計画に記載しているもの をAとし，検討がないか検討結果を計画に記載していないものを Cとした。項目により，例えば分析評価を定量的ではなく定性的 に行っているように，配慮事項に十分対応しているわけではない ものの, 配慮事項を踏まえた検討を一定程度進めているものが見 受けられたため，それらを中間的な評価としてBとした。

\section{（2）都市の生物多様性に関する既往研究の整理}

日本の都市を対象とした生物調査及び分布の規定要因に関する 文献を収集し整理した。対象は，鳥類，昆虫類，哺乳類，両生類， 植物とした。魚類や水草等は，生息地となる水域が，行政的区分 において都市域と異なる施策対象 (生物多様性国家戦略 ${ }^{1)}$ におい ては河川・湿原など）とされることが多いため, 今回は除外した。 研究対象地と緑地の指標 (量, 質, 配置) に着目して区分寸るこ とで, 研究対象の傾向を把握し, 今後の研究課題の考察を行った。

*国土交通省国土技術政策総合研究所 
表 - 1 生物多様性保全策としての緑の基本計画に関する分析の視点と評価区分

\begin{tabular}{|c|c|c|c|c|}
\hline 分析の視点 & 国土交通都市局 $(2011)^{2}$ にに示された二検訂項目 & A & $\mathrm{B}$ & $\mathrm{C}$ \\
\hline (0) 策定目的 & - & $\begin{array}{l}\text { 計画箖定の背景や目的に生物多様性保全老位 } \\
\text { 直つけ† }\end{array}$ & - & 生物多様性保全の位置つけなし \\
\hline (1) 現況調查 & 自然的条件及已济土会的条件の現況調查 & 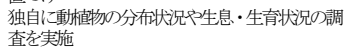 & 他の主体 (都道府県等) の調査結果を引用 & 動植物こ関する調查結果の情報なし \\
\hline (2) 分析評価 & 調查結果の分析·評価 & $\begin{array}{l}\text { 生物多榚性呆全の観点から緑地の重要度を定 } \\
\text { 量的几評価 }\end{array}$ & $\begin{array}{l}\text { 生物多栏性保全の観点から緑地の重要度を定 } \\
\text { 性的群価 }\end{array}$ & 緑地の重要度に関する評価なし \\
\hline (3) 課題整理 & 課題の整理 & $\begin{array}{l}\text { 緑の量、質、配置に関する課題こついての言及 } \\
\text { めり }\end{array}$ & - & $\begin{array}{l}\text { 緑の量、質、配置こ関する課題こついての言及 } \\
\text { なし }\end{array}$ \\
\hline (4) 目標設定 & 目標の設定 & $\begin{array}{l}\text { 目標種の設定等、生物多様性保全と関する目標 } \\
\text { 明示 }\end{array}$ & $\begin{array}{l}\text { 目標種の設定等、生物多樣生保全に関する目標 } \\
\text { を检付 }\end{array}$ & 生物多様性保全に関する目標の位置づけなし \\
\hline (5)配置方針 & 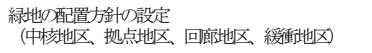 & $\begin{array}{l}\text { 地図上での表示や対象地の列挙等、即地的な配 } \\
\text { 置方針を明示 }\end{array}$ & $\begin{array}{l}\text { 中核地区、拠点地区、回郎地区、緩重地地区への } \\
\text { 配思在位置つけ }\end{array}$ & 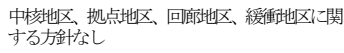 \\
\hline (6) 施策検討 & $\begin{array}{l}\text { 施策の検討 } \\
\text { 緥全、緑地の再生・創出、普及啓発等) }\end{array}$ & 生物多样性保全の観点からの施策を明示 & 生物多样性保全の観点からの施策なし & 施策なし \\
\hline (7) モニタリング & モニタリングの実施 & 動植物て関するモニタリングを䒠施 & 動植物に関するモニタリングを検付 & $\begin{array}{l}\text { 動植物に関するモニタリングについて位置づ } \\
\text { けなし }\end{array}$ \\
\hline
\end{tabular}

\section{3. 結果と考察}

\section{（1）生物多様性保全策としての緑の基本計画の現状と課題}

1）項目毎の分析

表 - 1 の視点と評価区分に基づく分析の結果，対象事例の全て が策定目的の一つに生物多様性保全を位置づけていた（図－1）。 また，ほとんどの事例で，保全，再生創出，普及啓発の各施策に 生物多様性保全の観点からの施策が明示されていた。

一方で，動植物に関する現況調査を実施している計画は 10 事 例，そのうち調査結果を緑地の定量評価につなげているものは 4 事例だった。特に柏市及び横浜市では、分析評価の根拠として論 文等の科学的知見を示していた（表－2）。課題整理の段階では, 全ての計画で緑の量が課題として言及されていたのに対し，緑の 質や配置に言及していない計画も見られた。これには各自治体に おける緑被率の違いが影響していると考えられる。例えば，緑被 率の低い地域では質よりも配置が重視され (台東区など)，緑被率 の高い地域では配置よりも質が重視され（釧路市など）ていた。 目標設定の段階では，目標種を設定している例はなく，港区及び 横浜市で検討予定とされていた。緑地の配置方針では，全ての計 画で中核地区に関する具体的方針を示していたのに対し，拠点地 区，回廊地区，緩衝地区について明示した事例は限られていた。 その中でも，名古屋市は 4 つの区分について具体的方針を示すと ともに，根拠として論文等の科学的知見を示していた（表-2)。 モニタリング実施を明示しているのは 3 事例であり，計画策定時 の調査の継続であった。計画策定時には半数の 10 事例で実施し ており，技術的な課題よりもコストや体制が課題と考えられる。 2）緑の基本計画策定手法の課題

分析の結果，優良事例とされた計画であっても，生物多様性保 全策の観点から見ると，生物多様性について策定目的に位置づけ られ, 各種施策の実施に当たって配慮すると明示されてはいるが, 現況調査に基づく定量的な評価，目標設定まで踏み込んで具体的 に検討されている事例はわずかであった（図－1）。個別生物種の 確認情報といった断片的な情報だけでは，体系的かつ計画的に $\mathrm{E}$ $\mathrm{N}$ 計画策定に取り組むことはできない8)。したがって緑の基本計 画が，地域の有効な生物多様性保全策として機能寸るには，各都 市における生物多様性に関する現状把握がまず必要と考えられる。 そのためには，効率的な調査方法や分析評価の方法について，科 学的知見に基づいた提案や手引き書等，行政担当者が参照可能な 技術資料が必要である。柏市や横浜市による緑地の分析評価（表 －2）のような取り組みが蓄積・共有されれば，より実効性の高 い計画立案につながるだろう。

また配置方針では，回廊地区については，必要性は示している ものの即地的な方針が示されていない事例が多く，緩衝地区につ いては考え方自体が示されていない事例が多かった。回廊地区に いては，ENの考え方が 1980 年代後半から欧米で着目され， 日本でも 2000 年代に関連書籍 8 等が刊行されたこともあり, 概 念としての理解は進んでいると考えられる。一方, 緩衝地区の記

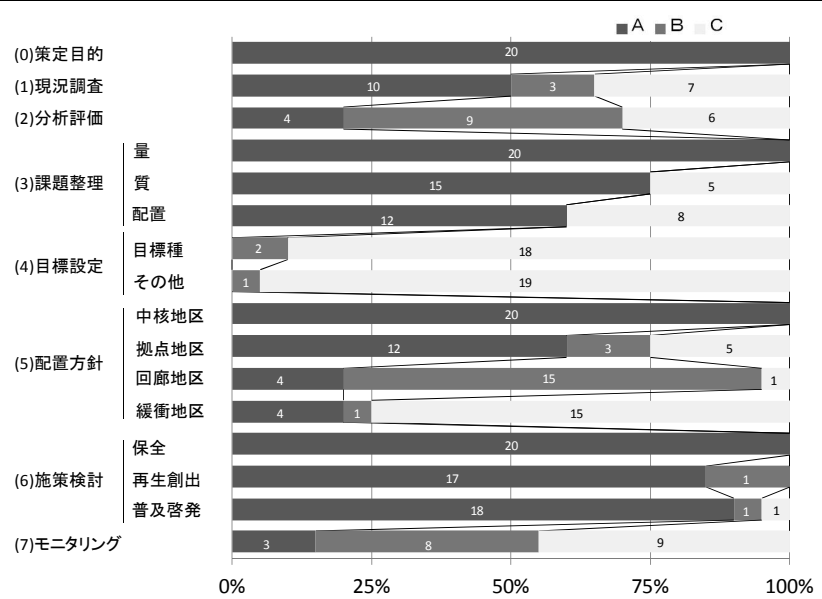

図 - 1 生物多様性保全策としての緑の基本計画の分析結果 表 - 2 生態学的知見を活用した計画検討の事例

\begin{tabular}{|c|c|}
\hline 自治体 & 内容 \\
\hline 柏市 & 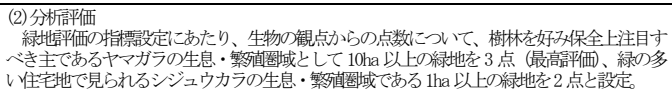 \\
\hline 横浜市 & 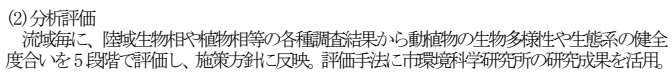 \\
\hline 名古屋市 & 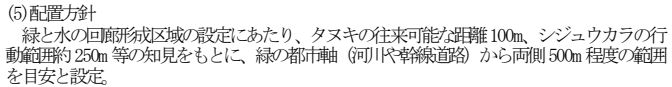 \\
\hline
\end{tabular}

載は一層少なかったが，近年になって景観生態学の分野において 重要性が明らかにされつつあるマトリクス (パッチ間の環境構造 や景観のモザイク性) 13)を計画用語的に翻訳したものであるため, 未だ認識が普及していないと考えられる。いずれにしろ，回廊・ 緩衝地区について即地的な配置計画とするためには, 名古屋市(表 －2）のように, 緑地に求められる量や質, 機能, マトリクスを 含めた効果的な配置について，科学的知見を活用し，地域の実情 に沿って検討を重ねることが必要である。

\section{（2）緑の基本計画策定手法の課題解決に資する科学的知見}

1）検討項目に応じた既往研究の整理

（1）の結果及び考察から，生物多様性保全策としての実効性 の観点からは，緑の基本計画の検討項目のうち，目標の設定，緑 地の分析評価，配置方針の検討に技術的な課題があると考えられ た。そこで既往研究を,「都市化による生物群集への影響」「生息・ 生育地としての緑地に求められる量, 質, 配置」の観点から整理 した（表 - 3)。前者の観点は，地域の都市化の程度や見込みを踏 まえて緑地を分析評価し目標を検討寸ることに，後者の観点は具 体的な配置方針の検討に，それぞれ活用することが可能である。

2) 研究課題の抽出 : 分類群及び対象地の偏りと研究のスケール

表 - 3 の整理結果から，都市を対象とした生態学研究には偏り があることがわかった。研究は，鳥類 21)などと昆虫類 35)曻どで特に 多い一方，哺乳類や両生類では限られることがわかった。また， 個々のパッチを対象とした研究が多い一方，コリドーやマトリク スに着目し,かつその効果を定量的に検証した論文は少なかった。 
これらの結果は，既往研究で指摘されてきた内容とも一致する。 すなわち，土屋ら（2013）141は，日本では，例えば東京圏を対象 とした沼田らによる大規模な都市生態系研究 15)をはじめ, 都市に おける鳥類やチョウ類の分布の規定要因などが研究されてきたが, 「都市生態学」は生態学分野の主流となっていないことを指摘し ている。同様に一ノ瀬（2010）5)も，ENの構筑方法について， 都市の樹林を利用する鳥類については概ね方法が明らかになった 一方, 他の分類群については昆虫類の研究が若干見られる程度で, 殆ど明らかになっていないとしている。これらの結果及び指摘は, 日本の都市において都市生態学に取り組むことの重要性と分類群 に偏らない研究の必要性を示している。

一方，緑地に求められる量，質，配置の観点からは，中核地区 や拠点地区の検討に資するいわゆるパッチの面積や植生構造に関 する知見が，どの分類群についても蓄積されていた。回廊地区の 検討に必要なコリドーの機能に関する知見も，鳥類や昆虫類（チ ヨウ類)においては蓄積されている 28), 43)。しかし市街化が進んだ 地域での回廊地区の機能については否定的な研究 29, 58)もあり, 適 用する際には詳細な検討が必要である。また緩衝地区の検討に必 要なマトリクスの機能に関する具体的な知見は，鳥類を対象とし た研究 ${ }^{33}$. 34), 61)が見られるのみであった。

以上を踏まえ, 表 - 3 の整理結果から見えてきた研究知見の不 足部分を, 今後の研究課題として 5 点挙げておきたい。

第 1 に，同時に複数分類群を対象とした研究を確認することは できなかった。分類群や移動能力 (飛翔性, 徘徊性), 生活史の違 いなどによって，当然ながら生物の分布を規定する要因や空間ス ケールは異なる。そのため, 現在のような特定の分類群を対象と した研究のみならず, 総合的な $\mathrm{EN}$ の構築に向けた基礎研究 5)が 求められる。第 2 に，鳥類 200や植物 65)関する研究によれば，地 域によって都市化の影響は異なるパターンで現れることが示唆さ れているが，多くの既往研究の対象地は東京を中心とする首都圈
と大阪・京都を中心とする近畿圈に集中している。一般則と整理

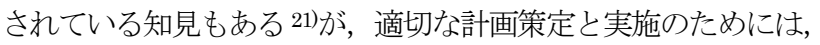
地域毎にきめ細かな検討と順応的な対応が要るだろう。第 3 に, 都市化による生物群集への影響を明らかにするためには，環境傾 度を十分に広く確保した範囲での調査, 長期にわたる継続的な調

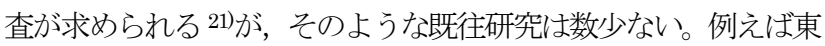
京は世界最大の都市圈であり, 都市生態学における国際的な議論 に資する観点 ${ }^{14)}$ 力らも, 幅広い 都市化傾度に沿って緑地の量・質・ 配置が生物多様性に及ぼす影響についての調査分析が求められる。 第 4 に, 今後は人口減少が進むなか一層限られた人員や費用で効 率的な生物調査と評価を行い, 緑地計画への反映と計画の実施を 行うことが求められている。そのため, 調査の効率化（例えば鳴 き声 59)，抜け殼 ${ }^{411} の$ 利用といった技術）や担い手の育成（例えば 企業社員調查 71)や市民協働調査 72) ) などの観点からの検討・検証 と知見の共有も必要である。第 5 に, 都市化の影響として緑地の 減少や分断化を想定して整理した表 - 3 には収まらない論文もあ った。例えば，攪乱の減少による常緑樹林化73)や再生樹林地にお ける更新の問題 74), 外来種の増加 75)等を指摘する研究が挙げられ る。これらは, 従来の枠組みで緑地を保全・再生・創出するだけ では対応できない課題であり, 解決に資する研究, 実践と, それ らを踏まえた新たな枠組みの検討が求められる。

\section{4. まとめと今後の課題}

本研究では, 都市における生物多様性保全に向けた緑の基本計 画の現状と課題を明らかにした上で，課題解决に資する既往研究 の知見を整理し今後の研究課題について考察した。現状では生物 多様性保全策として実効性の高い計画は多くなかったことから, 今後はきめ細かな評価分析や目標設定, 回廊地区や緩衝地区も含 めた配置方針を裏付ける研究，更には従来の緑地保全・再生・創 出の枠組みを超えた課題への対応につながる研究が必要であろう。

\section{表 - 3 既往研究における生態学的知見の整理注}

\begin{tabular}{|c|c|c|c|c|}
\hline \multirow{2}{*}{ 分類群 } & \multirow{2}{*}{ 都市化による生物群集への影響 } & \multicolumn{3}{|c|}{ 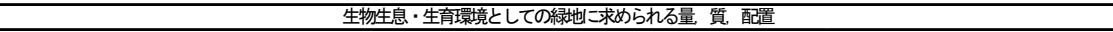 } \\
\hline & & 中核地区・拠点地区 (パツチ) & 回廊地区 (コリドー) & 緩重地区（マトリクス） \\
\hline 鳥類 & 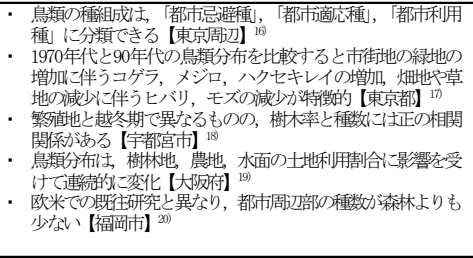 & 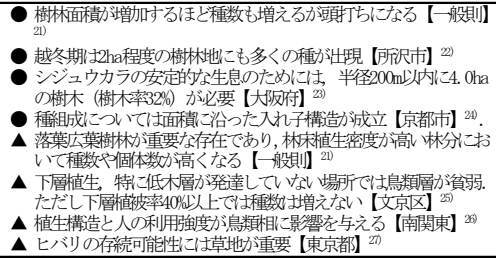 & 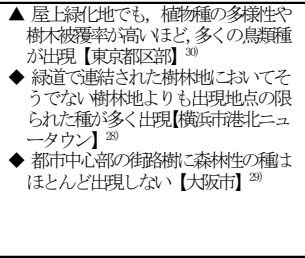 & 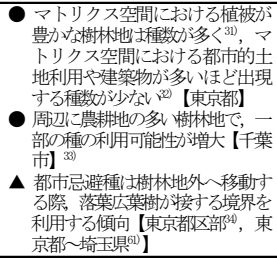 \\
\hline 昆虫類 & 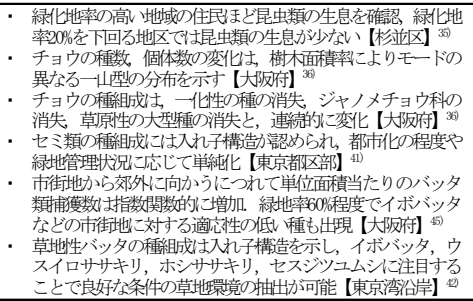 & 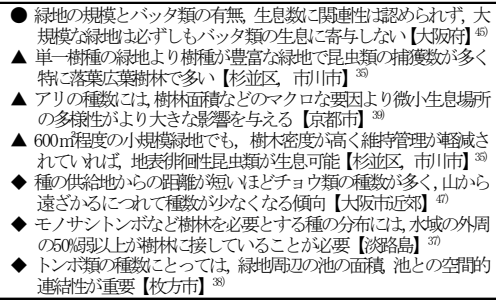 & 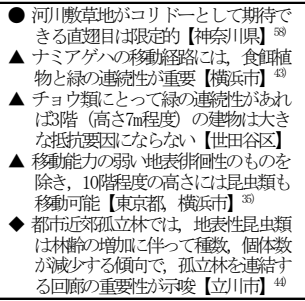 & 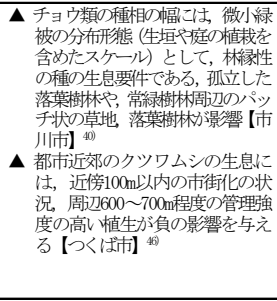 \\
\hline 哺爯類 & 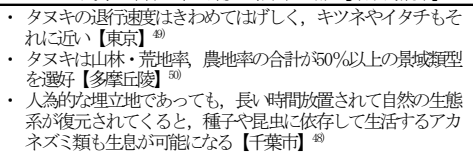 & 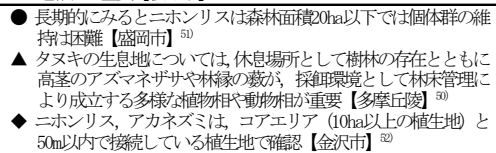 & 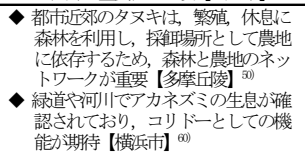 & \\
\hline 両生類 & 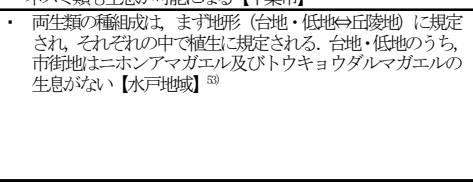 & 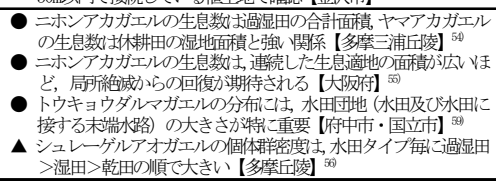 & 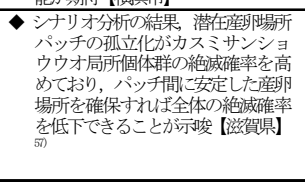 & 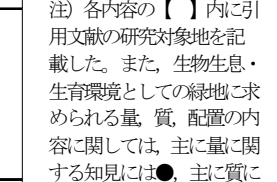 \\
\hline 植物 & 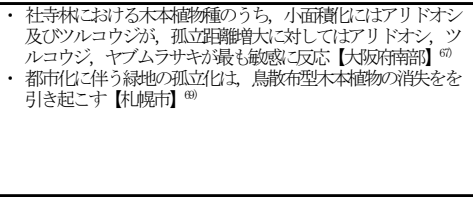 & 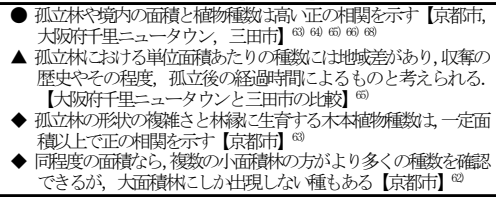 & 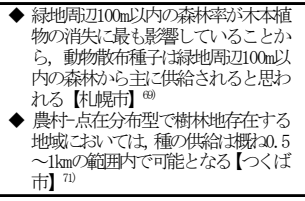 & $\begin{array}{l}\text { 関寸る知見にはム, 主に配 } \\
\text { 置に関する知見には、をを行 } \\
\text { 頭に付した。 }\end{array}$ \\
\hline
\end{tabular}




\section{補注及び引用文献}

1）環境省（2012）: 生物多様性国家戦略 2012-2020 : 環境省ホームページ〈http://www. biodic. go. jp/biodiversity/about/initiatives/>, 2014.3.19 更新, 2014.9.22参照

2) 国土交通省都市局 (2011) : 緑の基本計画における生物多様性の確保に関寸る技術的 配慮事項 : 国土交通省ホームページくwww. mlit. go. jp/crd/park/joho/houritsu/pdf/ H231001hairyojikou. pdf >, 2014.6.26 更新, 2014.9.22 参照

3）国土交通省都市・地域整備局公園緑地・景観課（2010）: 都市と生物多様性: 公園緑 地70 (6), 7-10

4）石川幹子 (2011) : 新たな都市に向けた緑の基本計画 : 公園緑地 71 (6)，7-9

5）一ノ瀬友博（2010）: 都市におけるエコロジカルネットワークのあり方 : 都市計画 $59(5), 38-41$

6）島田正文・津田秀文・倉方志磨・八色宏昌・並木崇・笹田勝寛 (2007) : 藤沢市ビ才 トープネットワーク基本計画策定の取組み：造園技術報告集 4，16-19

7) 緑の基本計画推進委員会 (2007) : 新編緑の基本計画ハンドブック，日本公園緑地協 会, 369pp

8) 都市緑化技術開発機構編 (2006) : 都市のエコロジカルネットワーク II, ぎょうせい, 235pp

9）いきものまちづくり研究会編（1992）: エコロジカルデザイン:ぎょうせい，300pp 10）徳江義宏・大澤啓志・今村史子 (2011) : 都市域のエコロジカルネットワーク計画 における動物の移動分散の距離に関する考察，日本緑化工学会誌37 (1)，203-206

11）日本公園緑地協会 : 緑の基本計画優良事例 40 選の選定について : 日本公園緑地協 会ホームページ〈http://www. posa. or. jp/outline/pdf/2013041802. pdf〉, 2013. 12.18 更新, 2014.9.22 参照

12）森本幸裕（2010）: 都市における生物多様性 : 環境情報科学 39 （3），51-57

13) 加藤和弘 (2010) : 都市の樹林地における鳥類の生息を規定する要因 : 都市計画 59 (5), $58-61$

14）土屋一彬・斉藤昌幸・弘中豊 (2013) : 都市生態学序説: 日本生態学会誌 63, 179-192

15）沼田真 (1987) : 都市の生態学 : 岩波書店, 225pp

16）加藤和弘 (2009) : 鳥類の種組成に基づく都市の鳥類生息環境評価指数の提案 : ラ 研 $72(5), 805-808$

17）植田睦之・加藤和弘・松野葉月・黒沢令子・成末雅恵 (2004）: 東京の鳥類相の変 化とその要因 : Strix 22, 1-20

18）平野敏明・遠藤孝一・仁平康介・金原啓一・樋口広芳（1985）: 宇都宮市における 樹木率と鳥類の種数との関係 : Strix4，33-42

19) Natuhara, Y. and Imai, C. (1996) : Spatial structure of avifauna along urban-rural gradients : Ecological Research11, 1-9

20) Mikami, K. 0. and Mikami, K. (2012) : Structure of the Japanese avian community from city centers to natural habitats exhibits a globally observed pattern, Landscape and Ecological Engineering (Online)

21）鵜川健也・加藤和弘（2007）: 都市の鳥類群集に影響する要因に関する研究の現状 と課題 : ラ研 71 (3), 299-308

22）一八瀬友博・加藤和弘（2003）: 都市域の小規模樹林地と都市公園における越冬期 の鳥類の分布に影響寸る要因 : ラ研 66 (5), 631-634

23）橋本啓史・夏原由博（2002）：ロジスティック回帰をもちいた都市におけるシジュ ウカラの生息環境適合度モデル : ラ研 65 (5), 539-542

24）橋本啓史・村上健太郎・森本幸裕（2005）：京都市内孤立樹林地における樹林性鳥 類の相刘種数一面積関係と種組成の入れ子パターン: 景観生態学 10 (1)，25-35

25) 加藤和弘 (1996) : 都市緑地内の樹林地における越冬期の鳥類と植生の構造の関係 : ラ研, 59 (5) , 77-80

26）岡崎樹里・秋山幸也・加藤和弘（2006）: 都市緑地における樹林地の構造と鳥類の 利用について: ラ研69 (5), 519-522

27）荒木田葉月・二橋弘宗 (2008) : 大都市圏におけるヒバリの繁殖商地と経年変化か らみた存続可能性の評価 : 保全生態学研究 13，225-235

28）森本豪・加藤和弘 (2005) : 緑道による都市公園の連結が越冬期の鳥類分布に与え る影響: ラ研 68 (5), 589-592

29）一ノ瀬友博（2006）: 大阪市中心部の街路樹と越冬期の鳥類の出現状況の関係 : ラ 研69 (5), 537-540

30）茂木哲一・柳井重人（2005）: 東京都区部の屋上緑化地における鳥類の分布特性に 関寸る研究 : ラ研 68 (5), 597-600

31）鵜川健也・加藤和弘 (2007) : 都市域の樹林地および樹林地を取り巻く空間の環境 条件と鳥類群集との関係 : ラ研 70 (5)，487-490,

32）岡崎樹里・加藤和弘（2004）: 都市緑地の孤立化が鳥類相の退行に与える影響 : 環 境情報科学論文集 18，439-444

33) Morimoto, T., Katoh, K., Yamaura, Y. and Watanabe, S. (2006) : Can surrounding land cover influence the avifauna in urban/suburban woodlands in Japan? : Landscape and Urban Planning 75 (1-2), 143-154

34）小川直哉・加藤和弘（2010）: 都市緑地における鳥類のパッチ境界を越える移動と 境界概外接部の土地被服との関係 : 環境情報科学論文集 $24 ， 67-72$

35）島田正文 (1997) : 都市における昆蝢の生息と緑化に関寸る研究，千葉大学大学 院博士論文, $167 \mathrm{pp}$

36）夏原由博（2000）: 都市近郊の環境傾度に沿ったチョウ群集の変化：ラ研63（5), $543-546$

37）一ノ瀬友博・森田年則（2002）: 兵庫県北淡町の農村地域のため池におけるトンボ 類の分布とそれを規定する要因について: ラ研65（5)，501～506

38）李承恩・盛岡通・藤田壮（2001）：トンボ類を指標生物とした都市域におけるビオ トープの空間的特性の評価 : 土木学会論文集 $671,1-11$

39）由井亜右子・夏原由博・村上健太郎・森本幸裕（2001）: 都市孤立林におけるアリ の種数に影響する要因 : 日本緑化工学会誌 27 (1) : 78-83
40）横田樹広・武内和彦（2006）: 高解像度緑被モニタリングによる都市内小規模緑被 の分布把握とチョウ類を指標とした生態系ネットワーク機能の評価:都市計画論文集 41 (3), 361-366

41）徳江義宏・今村史子・大澤啓志（2013）: 都市域の樹林地におけるセミ類の生息分

布を規定する環境要因 : ラ研 76 (5), 465-468

12）板川暢・一八瀬友博・片桐由希子・大澤攵志・石川幹子 (2012) : 東京湾㳂岸部埋 立地における緑被分布とバッ夕類の生息分布との関係について:ラ研 75 (5), 621-624 43）小田原卓郎・林豊・米村惣太郎・西尾伸也（2006）: 都市の生態系ネットワークに 関寸る実験的研究 : 清水建設研究報告 83，25-36

44）谷脇徹・久野春子・細田浩司（2005）都市近郊の小規模孤立林における地表性昆虫 類の群集構造の変化：日本緑化丁学会誌 30 (3)，552-560

45）養父志乃夫・山田宏之・中島敦司・中尾史郎・松本勝正（2001）：大規模市街地内 から郊外地にか计てのバッ夕類生息密度の変化について: ラ研64 (5)，595-600

46）徳江義宏・大澤䓵志（2014）: 都市近郊の農村域におけるクツワムシの生息実態 : ラ研 77 (5), 599-602

47）今井長兵衛・夏原由博（1996）: 大阪市とその周辺の緑地のチョウ相の比較と島の 生物地理学の適用 : 環動昆 8 (1)，23-34

48）金森正臣 (1981) : 変化する都市のネズミ相 : 生活と環境26 (4), 18-23

49) 千羽晋示 (1973): 動物の生息環境の変化と退行現象:季刊自然科学と博物館 40 (2), 69-73

50）園田陽一 (2007) : 都市環境における野生哺乳類の生息地としての緑地の管理・配 置に関寸る研究 明治大学大学院博十論文 $139 \mathrm{pp}$

51）西千秋・出口善隆・青井俊樹（2011）: 盛岡市の都市近郊林に生息するニホンリス の雌雄別行動圈面積および行動圏重複率とオニグルミの資源量との関係:哺乳類科学 51 (2), 277-285

52) 井本郁子・川上智稔・寺尾晃二・井手任 (2002) : ニホンリスとアカネズミを指標 とした樹林性動物の生息環境ネットワーク地図の作成:国際景観生態学会日本支部会 報 7 (2)，51-56

53）大澤啓志・日置佳之・松林健一・藤原宣夫・勝野武彦 (2003)：種組成を用いた解 析による両生類の生息域予測に関寸る研究 : ラ研66 (4)，327-336

54）大澤啓志・勝野武彦 (2002) : 都市域の公園・保全緑地におけるアカガエル類生息 数の概数に影響孝及ぼす環境条件: ラ研 63 (5)，513-516

55）夏原由博・神原忍（2001）：ニホンアカガエルの大阪府南部における生息適地と連 結性の推定 : ラ研, 64 (5), 617-620

56）大澤啓志・勝野武彦 (2000) : 多摩丘陵南部におけるシュレーゲルアオガエル生息 の環境条件の把握と保全に関する考察 : ラ研63 (5)，495-500

57）夏原由博・三好文・森本幸裕（2002）：メ夕個体群存続可能性分析を用いたカスミ サンショウウオの保護シナリオ : ラ研65（5)，523-526

58）根津準一郎・大澤啓志・勝野武彦 (2011) : 都市域内の河川緑地における直翅目の 生自実能·日本緑化丁学会誌 37 (1) , 195-198

59）山本康仁・千賀裕太郎（2012）: 都市化により分断化された水田におけるトウキョ ウダルマガエルRana porosa porosaの分布と環境要因の関係:保全生態学研究17 (2), 175-184

60）黒田貴綱・勝野武彦 (2007) : 都市近郊域における異なる土地利用タイプとアカネ ズミの生息との関係 : ラ研 70 (5), 479-482

61）加藤和弘・神山高義（2014）: パッチ状樹林地の境界を越えて移動する鳥類の種組 成とパッチ外周の土地被覆との関係

62）村上健太郎・牧野覀友美・森本幸裕・里村明香（2005）: 都市孤立林の植物種多栏 性の保全では単一の大面積林と複数の小面積林のどちらが重要か? : ラ研68（5） 633-636

63）村上健太郎・森本幸裕（2000）: 京都市内孤立林における木本植物の種多様性とそ の保全に関寸る景観生態学的研究 : 日本緑化工学会誌 $25,345-350$

64）村上健太郎・森本幸裕（2001）: 京都市内孤立林におけるシダ植物の種数と面積と の関係 : 日本緑化工学会誌 27 (1)，290-291

65）石田弘明・戸井可名子・武田義明・服部保（2002）：大阪府千里丘陵一帯に残存寸 る孤立二次林の樹林面積と種多様性，種組成の関係 : 植生学会誌 19 (2)，83-94

66）今西亜友美・今西純一・村上健太郎・森本幸裕・里村明香 (2005) : 京都市内の非 樹林緑地としての神社境内における草本植物の種数と種の出現パターン:日本緑化工 学会誌 31 (2)，278-283

67）村上健太郎・上久保文貴・泉本法子・森本幸裕（2009）：都市域の孤立神社林にお ける木本種の多様性保全のための焦点生物種選定手法の適用 : 景観生態学 14（1）, $41-51$

68）服部保・上甫木昭春・小館誓治・熊懷恵美・藤井俊夫・武田義明（1994）: 三田市 フラワータウン内孤立林の現状と保全について : ラ研57（5）,217-222

69）矢部和夫・吉田恵介・金子正美（1998）：札幌市における都市化が植物相に与えた 影響: ラ研 61 (5), 571-576

70）井手任・守山弘・原田直國（1989）：農村地域における樹林地の分布特性と生態系 維持機能 : 造園杂隹志 52 (5), 169-174

71）岩浂翼・増澤直・ 三輪隆・小黒芳生・横山潤・中静透（2014）: 生物多様性への 貢献を主眼とした企業緑地評価ツール及び簡易生物調査ツールの性能評価 : 景観 生態学19(1), 69-82

72）横浜市環境創造局:市民協働生き物調査の記録: 横浜市ホームページくhttp://www. city. yokohama. 1g. jp/kankyo/mamoru/rikuiki/>, 2013. 12.16 更新, 2014.9.22 参照 73）田端敬三・橋本啓史・森本幸裕・前中久行（2007）：下鴨神社糺の森における林冠 木の枯死とそれに伴う木本実生の侵入定着過程 : 日本緑化工学会誌，33(1)，53-58 74）千原裕（2012）：自立した森「自然文化園」の挑戦：景観の生態史観：180-184 75）吉田葵・林誠二・石川幹子 (2013) : 都市緑地における種組成の差異が雨水涵着機 能に与える影響に関寸る研究:都市計画論文集 48(3)，1011-1016 